\title{
Intake and digestibility of rations with distillery yeasts byproducts, molasses and ammoniated sugar cane tops in lambs in total confinement
}

Consumo y digestibilidad de raciones con levaduras de destilería, melaza y cogollo de caña amonificado en corderos confinados totalmente

Primera-Campos F, Nouel-Borges GE, Sánchez-Blanco R. Intake and digestibility of rations with distillery yeasts byproducts, molasses and ammoniated sugar cane tops in lambs in total confinement. Rev Colombiana Cienc Anim. Recia. 2020; 12(1):e731. DOI: https://doi.org/10.24188/recia.v12. n1.2020.731

Universidad de Sucre, Colombia

Los autores permiten a RECIA reimprimir el material publicado en él. En caso de que un autor quiera traducir o usar una publicación parcial o completa de nuestro Diario, el autor debe obtener un permiso por escrito del editor de la revista.

Copyright (C) 2020. El (los) autor (es), Revista Colombiana de Ciencia Animal - RECIA. 2020. Este es un artículo de acceso abierto distribuido bajo los términos de Creative Commons Attribution 4.0 (https://creativecommons.org/licenses/by-nc-sa/4.0/), El uso, distribución o reproducción está permitido, siempre que se acrediten al autor original y al propietario del copyright y que se cite la publicación original en esta revista, de acuerdo con la práctica académica aceptada. No se permite el uso, distribución o reproducción que no cumpla con estos términos..

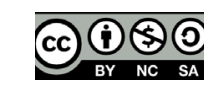




\title{
Intake and digestibility of rations with distillery yeasts byproducts, molasses and ammoniated sugar cane tops in lambs in total confinement
}

\author{
Consumo y digestibilidad de raciones con levaduras de destilería, melaza y cogollo de \\ caña amonificado en corderos confinados totalmente
}

\section{Félix Primera-Campos}

Universidad Lisandro Alvarado. Facultad de Agronomía. Unidad de Investigación en Producción Animal. Estado Lara, Venezuela.

felixprimera01@yahoo.com

(iD https://orcid.org/0000-0002-3751-0253

\section{Gustavo Enrique Nouel Borges}

Biominbloq CA, Gerencia General, Municipio Simón Planas, estado Lara, Venezuela.

genouelb@yahoo.es

(D) https://orcid.org/0000-0002-3746-4234

\section{Roseliano Sánchez-Blanco}

Universidad Lisandro Alvarado. Facultad de Agronomía. Unidad de Investigación en Producción Animal. Estado Lara, Venezuela.

roselianoblanco@ucla.edu.ve

(iD) https://orcid.org/0000-0003-3562-3307

\author{
DOI: https://doi.org/10.24188/recia.v12.n1.2020.731
}

Recepción: 29 Julio 2019

Aprobación: 30 Diciembre 2019

Publicación: 5 Febrero 2020

\begin{abstract}
Were evaluated sodium bicarbonate. $\mathrm{F}_{1}$ - and urea.- $\mathrm{F}_{2^{-}}$(two factors), each factor at two inclusion levels ( $\mathrm{F}_{1}$ and $\mathrm{F}_{2}: 0$ and $1 \%$ ), and its effect on intake and digestibility in rations with byproduct of the fermentative process of starches and / or molasses (mixture of yeast and unfermented material).-LD.-, sugarcane molasses and ammoniated sugar cane tops for lamb. Eight crossbred lamb $(19.31 \pm 5.96 \mathrm{~kg} / \mathrm{lamb})$ was included in a $2 \times 2$ factorial in a $4 \times 4$ Latin square design. Treatments were combinations of $\operatorname{LD}\left(14 \%\right.$ in $\mathrm{T}_{1}, 13.8 \%$ for $\mathrm{T}_{2}, \mathrm{~T}_{3}$ and $\left.\mathrm{T}_{4}\right)$ and molasses $\left(26 \%\right.$ in $\mathrm{T}_{1}, 25.8 \%$ for $\mathrm{T}_{2}, \mathrm{~T}_{3}$ and $\left.\mathrm{T}_{4}\right)$, with or without urea, and / or sodium bicarbonate to $1 \% \mathrm{w} / \mathrm{u}$, and source of fiber were used $60 \%$ of ammoniated sugar cane tops in all treatments. The supply of rations was gradually adjusted to $7 \%$ dry matter (DM) of body weight (28 $\pm 8.66 \%$ rejection of the offer), digestibility was measured by total collection for seven days adaptation period preceded of seven day. Differences $(\mathrm{p}<0.01)$ for intake where intake had the highest $\mathrm{T}_{2}$ and $\mathrm{T}_{4}$ the lower $(1239 \mathrm{vs} 1066 \mathrm{gDM} / \mathrm{animal} / \mathrm{day})$ in the digestibility of organic matter $(\mathrm{p}<0.01)$ were found where $\mathrm{T}_{4}^{2}$ reached one $72 \%$ while the $\mathrm{T}_{2}$ was the lowest with $57.35 \%$. The coefficients of digestibility of hemicelluloses, acid detergent fiber, neutral detergent fiber and were different $(\mathrm{p}<0.01)$ and were higher in the same $\mathrm{T}_{1}$. The results showed that $\mathrm{T}_{4}$ was the best treatment, urea and sodium bicarbonate can be used effectively with agro-industrial byproducts in lambs in confinement.
\end{abstract}

Keywords: Lambs, distillery yeast, sodium bicarbonate.

\section{RESUMEN}

Se evaluaron nivel de bicarbonato de sodio.- $\mathrm{F}_{1}-\mathrm{y}$ nivel de urea.- $\mathrm{F}_{2^{--}}$, cada factor a dos niveles $\left(\mathrm{F}_{1}\right.$ y $\mathrm{F}_{2}: 0$ y $\left.1 \%\right)$ de inclusión, y su efecto sobre el consumo y digestibilidad en raciones con subproducto del proceso fermentativo de los almidones y/o de la melaza (mezcla de levaduras y material no fermentado).-LD.-, melaza y cogollo de caña para corderos. Ocho corderos mestizos (19.31 $\pm 5.96 \mathrm{~kg} /$ animal), fueron incluidos en arreglo factorial $2 \mathrm{x} 2$ con diseño en cuadrado latino $4 \times 4$. Los tratamientos fueron combinación de $\mathrm{LD}\left(14 \%\right.$ para $\mathrm{T}_{1} 13.8 \%$ para $\mathrm{T}_{2}, \mathrm{~T}_{3}$ y $\left.\mathrm{T}_{4}\right)$ y melaza $\left(26 \%\right.$ para $\mathrm{T}_{1} 25.8 \%$ para $\mathrm{T}_{2}, \mathrm{~T}_{3}$ y $\mathrm{T}_{4}$ ), con o sin urea y/o bicarbonato de sodio al $1 \%$ c $/$ u., como fuente de fibra se utilizó $60 \%$ de cogóllos de caña amonificado en todos los tratamientos. Oferta de raciones se ajustó gradualmente hasta 7\% de MS del peso vivo (rechazo $28 \pm 8.66 \%$ de lo ofrecido), digestibilidad se determinó por colección total, durante siete días, precedidos por siete días de adaptación. Se encontraron diferencias $(\mathrm{p}<0.01)$ para consumo donde $\mathrm{T}_{2}$ presento mayor consumo y $\mathrm{T}_{4}$ el menor $(1239$ vs 1066 gMS/animal/día), la digestibilidad de la materia orgánica $(\mathrm{p}<0.01)$ donde $\mathrm{T}_{4}$ alcanzó $72 \%$ mientras que el $\mathrm{T}_{2}$ fue 
el menor con 57.35\%. Los coeficientes de digestibilidad de fibra ácido detergente, fibra neutro detergente y hemicelulosa fueron diferentes $(\mathrm{p}<0.01)$ y los mismos fueron superiores en $\mathrm{T}_{1}$. Resultados obtenidos demostraron que $\mathrm{T}_{4}$ fue el mejor tratamiento, y el bicarbonato de sodio puede usarse eficientemente con los subproductos agroindustriales en corderos en confinamiento.

Palabras claves: Corderos, Lavaduras de destilería, bicarbonato de sodio

\section{INTRODUCTION}

The rearing of post-weaning lambs requires balanced diets capable of maintaining weight gains that facilitated attaining the weight at the time of slaughter or the first service quickly $(1,2)$, at a competitive feeding cost and preferably using readily available resources locally $(3,4)$. For the year 2014 in Venezuela, 102,877 hectares of sugarcane were harvested, obtaining 6,483,755 tons of cane, of which 367,000 tons of molasses were extracted (5).

Likewise, according to the same source, for the same year 2014, 232,528 sheep were slaughtered, with a yield of 16.00 $\mathrm{kg} /$ carcass, which generated 3,718 tons of carcass meat. From harvest sugar cane, between 411,508 and 514,385 tons of dry matter of buds can be obtained (own calculations according to data collected in Lara State, Venezuela), with an average of $89.7 \%$ of dry matter, $5.1 \%$ of ash, $3.7 \%$ crude protein, $78.2 \%$ fiber insoluble in neutral detergent, $40.7 \%$ fiber insoluble in acidic detergent and $11.54 \%$ lignin (6). When the fibrous by-products of sugar cane are dry-ammoniated (using the moisture of the fresh vegetable), it is possible to increase the availability of nitrogen in the plant material and release the components of the lignin cell wall $(7,8)$ improving the nutritional value for ruminants, increasing the intake of dry matter and the digestibility of the cell wall (8).

Most of the sheep assets of Venezuela are located in the province of dry sub-humid to humid, which is characterized as follows: altitude 511-921 meters above sea level, average temperature between 25 and $27^{\circ} \mathrm{C}$, precipitation $663-805$ $\mathrm{mm}(\mathrm{mm})$, evapotranspiration 1,186-1,274 mm, humidity deficit of 0-637 mm, dry months of 4 to 11 , highly seasonal according to Andrade-Benítez (9), in the states of Lara, Falcón and Zulia (10), with strong limitations for the production of fodder throughout the year (11).

The liquor industry uses molasses and / or cereals, not suitable for human intake to make drinks such as rum, whiskeys among others, as a by-product of the fermentative process of starches and / or reducing sugars of molasses is a mixture of yeast and unfermented material of interest in animal feed, especially in sheep and lambs, whose composition on dry basis can vary from 89.1 to $94.2 \%$ of DM, 25.4 to $49 \%$ of CP, $8.9 \%$ of EE, 41.8 to $42.7 \%$ NDF, 3.95 to $5.6 \%$ of ashes (12, 13, 14 ). Due to the need to offer rations that can cover the nutritional requirements of weaned lambs, which are exploited in dry areas, it was proposed to evaluate locally available resources, such as: sugar cane harvest residues mixed with brewer's yeast, molasses, urea, and / or sodium bicarbonate to determine its effect on the intake of rations and its digestibility in lambs confined after weaning.

\section{MATERIALS AND METHODS}

Location. Animal Production Research Unit (UIPA), Experimental Shed in Small Ruminants, Agronomy Deanship of the Lisandro Alvarado Centroccidental University, (UCLA), Palavecino Municipality, Lara State. The average annual climatic data of the area are: temperature of $25^{\circ} \mathrm{C}$, precipitation of $812.6 \mathrm{~mm}$, relative humidity of $74.6 \%$, solar radiation of 371 cal cm $\mathrm{cm}^{-2}$ and evaporation of 2,084.9 $\mathrm{mm}$ and a height of 550 meters above sea level (15). The experiment was carried out from the month of June to the month of December.

Animals, management and treatments. Combinations of yeasts (byproduct of the fermentative process of starches and / or molasses.-mixture of yeast and unfermented material.-) of liquor factory and sugarcane molasses, with urea and / or $1 \%$ sodium bicarbonate (Table 1), in a completely random $2 \times 2$ factorial arrangement in a $4 \times 4$ Latin square design (Table 2). Two factors were evaluated: sodium bicarbonate level- $F_{1}-$ and urea level- $F_{2}{ }^{-}$, each factor at two levels: $F_{1}$ in 0 and $1 \%$; $\mathrm{F}_{2}$ at 0 and $1 \%$ ) of inclusion, each treatment was a complementary part of the ration offered at a rate of $40 \%$ of the total dry matter, the other $60 \%$ of the dry matter of the ration was an ammoniated sugar cane tops.

Statistical model: factor I. level of sodium bicarbonate with two (2) levels, factor II: level of urea with two levels, yijk being the answers for the k-th experimental unit of level I of factor I and $\mathrm{j}$ of factor II

$\mathrm{y}_{\mathrm{ijk}}=\mu+\mathrm{T}_{\mathrm{i}}+\beta_{\mathrm{j}}+\gamma_{\mathrm{ij}}+\varepsilon_{\mathrm{ijk}}$

with $\mathrm{i}=0,1 ; \mathrm{j}=0,1$ and $\mathrm{k}=1,2,3,4$

With the hypotheses:

$\mathrm{H} 01^{\gamma}=0 \vee \mathrm{i}, \mathrm{j}$

$\mathrm{H} 02 \mathrm{~T}_{\mathrm{ij}}^{\mathrm{j}}+\overline{\mathrm{y}}_{\mathrm{i}}=0 \vee \mathrm{i}$

H03 $\beta_{j}^{i}+\bar{y}_{j}^{i}=0 \vee j$

Determining the nutritional quality of these mixtures, taking samples of forages and raw materials that were analyzed to determine dry matter, crude protein, energy and ash by the methods described by the AOAC (16) and fractions of the cell wall, as insoluble fiber in neutral detergent and acid, and hemicellulose by the methodology described by Van Soest et al 
(17). As well as the intake and digestibility in sheep described by Nouel-Borges et al (3), with the use of 8 young animals (2 per treatment and per period) crossbreed West African, $19.31 \pm 5.96 \mathrm{Kg}$ Initial Live Weight (LW), an average metabolic weight (MW, LW ${ }^{0.75}$ ) of 9, 58 $\pm 0.14 \mathrm{~kg}$ during the experiment, in four experimental periods of 14 days each, with 7 days of habituation and 7 days of observation to make the measurements of intake and feces of $24 \mathrm{~h}$, for a total of 56 days ( 3 ), controlling the experimental period and the animals (Table 1), determining the food intake and the apparent digestibility of the nutrients when they receive a base ration of ammoniated sugar cane tops (18). For the analysis of all the variables described, the software Statistix for Windows version 8.0 (19).

Table 1. Composition of the Experimental Treatments Used.

\begin{tabular}{ccccc}
\hline \multirow{2}{*}{ Ingredients (\%) } & \multicolumn{4}{c}{ Experimental Rations } \\
\cline { 2 - 5 } & $\mathbf{T}_{1}$ & $\mathbf{T}_{2}$ & $\mathbf{T}_{3}$ & $\mathbf{T}_{4}$ \\
\hline Molasses & 14 & 13.8 & 13.8 & 13.6 \\
Yeast & 26 & 25.8 & 25.8 & 25.6 \\
Urea & 0 & 0 & 0.4 & 0.4 \\
Sodium bicarbonate & 0 & 0.4 & 0 & 0.4 \\
CCA & 60 & 60 & 60 & 60 \\
\hline
\end{tabular}

CCA: Ammoniated sugar cane tops

The percentages that represent each one of the raw materials used for the elaboration and composition of the experimental rations are presented in Tables 2, 3 and 4. The combination of molasses and yeasts, in a proportion of 35\% Molasses and $65 \%$ yeast, comes from a pre-test performed just before the experiment, where 12 combinations of molasses and yeast were tested, to achieve the best way to preserve the agro-industrial by-product, stabilizing it at a $\mathrm{pH}$ of 4.55 (initial of 4.62 , after 6 weeks of weekly measurements, June-July) and with the minimum loss of energy in the pre-mix. The agroindustrial by-product was collected in a stainless steel tank of 10,000 liters, at the outlet temperature of $84^{\circ} \mathrm{C}$, it was allowed to cool to room temperature for 24 hours, $90 \%$ of the supernatant liquid was extracted by siphons on the surface and the Tank bottom (1000 liters) was collected from a lower valve in a 250 liter plastic tank, to be processed later. Due to the acidity of the pre-mix, it is decided to propose the incorporation of sodium bicarbonate as a pH modulator in the rations evaluated.

Table 2. Arrangement and Experimental Design.

\begin{tabular}{ccccccccccc}
\hline & Animal & $\mathbf{1}$ & $\mathbf{2}$ & $\mathbf{3}$ & $\mathbf{4}$ & $\mathbf{5}$ & $\mathbf{6}$ & $\mathbf{7}$ \\
\hline \multirow{4}{*}{ PERIODS } & $1-14$ & $\mathrm{~T}_{1}$ & $\mathrm{~T}_{1}$ & $\mathrm{~T}_{2}$ & $\mathrm{~T}_{2}$ & $\mathrm{~T}_{3}$ & $\mathrm{~T}_{3}$ & $\mathrm{~T}_{4}$ & $\mathrm{~T}_{4}$ \\
& $15-28$ & $\mathrm{~T}_{4}$ & $\mathrm{~T}_{4}$ & $\mathrm{~T}_{1}$ & $\mathrm{~T}_{1}$ & $\mathrm{~T}_{2}$ & $\mathrm{~T}_{2}$ & $\mathrm{~T}_{3}$ & $\mathrm{~T}_{3}$ \\
& $29-42$ & $\mathrm{~T}_{3}$ & $\mathrm{~T}_{3}$ & $\mathrm{~T}_{4}$ & $\mathrm{~T}_{4}$ & $\mathrm{~T}_{1}$ & $\mathrm{~T}_{1}$ & $\mathrm{~T}_{2}$ & $\mathrm{~T}_{2}$ & $\mathrm{~T}_{4}$ \\
& $43-56$ & $\mathrm{~T}_{2}$ & $\mathrm{~T}_{2}$ & $\mathrm{~T}_{3}$ & $\mathrm{~T}_{3}$ & $\mathrm{~T}_{4}$ & $\mathrm{~T}_{1}$ & $\mathrm{~T}_{1}$ \\
\hline
\end{tabular}

Table 3. Composition of the Evaluated Treatments.

\begin{tabular}{ccccc}
\hline Bromatological & \multicolumn{4}{c}{ Treatments } \\
\cline { 2 - 5 } Composición & $\mathbf{T}_{1}$ & $\mathbf{T}_{2}$ & $\mathbf{T}_{3}$ & $\mathbf{T}_{4}$ \\
\hline DM (\%) & 83.41 & 67.22 & 82.51 & 90.62 \\
OM (\%) & 71.98 & 55.85 & 72.20 & 79.51 \\
GE (Mcal/g) & 3.87 & 3.75 & 3.85 & 3.85 \\
CP (\%) & 16.48 & 16.35 & 16.14 & 18.73 \\
NDF (\%) & 59.26 & 60.07 & 51.67 & 56.47 \\
ADF (\%) & 40.15 & 41.84 & 37.65 & 39.97 \\
Hemicell(\%) & 19.11 & 18.23 & 14.02 & 16.50 \\
\hline
\end{tabular}

DM: Dry matter, OM: Organic matter, CP: Crude protein, GB: Gross energy, ADF: Fiber insoluble in acid detergent, NDF: Fiber insoluble in neutral detergent. Hemicell: Hemicellulose

Table 4. Composition of raw materials.

\begin{tabular}{cccc}
\hline \multirow{2}{*}{ Bromatological Composición } & \multicolumn{3}{c}{ raw materials } \\
\cline { 2 - 4 } & Yeast & Molasses & CCA \\
\hline DM (\%) & 82.63 & 14.74 & 73.5 \\
OM (\%) & 62.88 & 66.54 & 68.3 \\
GE (Mcal/g) & 3.75 & 3.76 & 3.31 \\
CP (\%) & 2.99 & 50.97 & 7.3 \\
NDF (\%) & -- & 42.74 & 56.9 \\
ADF (\%) & -- & 24.86 & 39.9 \\
\hline
\end{tabular}

CCA: Ammoniated sugar cane tops 
The animals received the rations in individual pens, they had water to freedom in each pen, with cement floor and roof, and the feeders were $0.5 \mathrm{~m}$ long and $10 \mathrm{~kg}$ capacity and an area of $1.5 \mathrm{~m}^{2}$ for each animal. At the beginning of the afternoon (12:00 m), a well-known amount of ammoniated sugar cane was offered, uniformly mixed with the ration emphasizing that treatments previously dehydrated, were offered to the animals. For the dehydration process of the mixtures, a handmade coffee dryer was used, subjecting the mixtures to temperatures that oscillated between $60-80^{\circ} \mathrm{C}$ for a period of time of 24 hours. In the same way, the intake was measured daily by the difference between what was offered and what was rejected in the feeders at the same time of the afternoon, maintaining a 5\% excess in the feeders (in order to guarantee intake to freedom), for the weighing was using an electronic scale with a capacity of $4 \mathrm{~kg}$ and 1 gram of appreciation. The animals were dewormed 3 months before the test (at weaning) and the dose was repeated once it was started, moxidectin was placed in a $1 \%$ solution for injection (Cydectin ${ }^{\circledR}$ ), at a rate of $0.5 \mathrm{cc} /$ animal subcutaneously.

The sugarcane tops were chopped in a chopping machine (2.5 $\mathrm{cm}$ in length), then dry ammoniated, using pearl urea, at a rate of $3 \mathrm{Kg}$ per $100 \mathrm{Kg}$ of sugar cane tops $(7,18)$, without adding water because the bud possessed more than $40 \%$ moisture. In order to facilitate the ammonification, the material was mixed with the urea and stored in black polyethylene bags, eliminating excess air and sealing them.

\section{RESULTS}

The highest DM intakes, cell wall components (NDF, ADF, hemicellulose) and CP reached (Table 5) were higher for $\mathrm{T}_{2}$, with the highest $\mathrm{OM}$ intake for $\mathrm{T}_{4}$. With an apparent digestibility of dry matter and similar energy for all treatments, greater $\mathrm{OM}$ digestibility for $\mathrm{T}_{4}$ and $\mathrm{T}_{3}$, greater cell wall digestibility (NDF) and hemicellulose for $\mathrm{T}_{2}$, higher digestibility of ADF for $\mathrm{T}_{4}$ and $\mathrm{T}_{2}$, and a greater digestibility of the $\mathrm{CP}$ for $\mathrm{T}_{4}$ and $\mathrm{T}_{1}$. In general, $\mathrm{T}_{2}$ presented the highest intake with the best overall performance of fiber digestion. But the $\mathrm{T}_{4}$, with a lower intake in DM per kg of MW and a higher intake of CP, the digestion of OM was the highest, as well as that of ADF and CP, with an intermediate level of digestion of the wall cellular (NDF).

Table 5. Analysis of Variables for intake and digestibility by treatment.

\begin{tabular}{|c|c|c|c|c|c|}
\hline \multirow{2}{*}{ Variables } & \multicolumn{4}{|c|}{ Tratamientos } & \multirow{2}{*}{$\mathbf{P}$} \\
\hline & $\mathrm{T}_{1}$ & $\mathrm{~T}_{2}$ & $\mathbf{T}_{3}$ & $\mathrm{~T}_{4}$ & \\
\hline DM (g) intake & $1059.5^{b}$ & $1239.3^{a}$ & $1111.5^{\mathrm{ab}}$ & $1065.7^{b}$ & 0.0145 \\
\hline OM $(\mathrm{g})$ intake & $758.81^{\mathrm{ab}}$ & 696.55 & $808.49^{\mathrm{ab}}$ & $843.09 a$ & 0.0105 \\
\hline NDF (g) intake & $624.72^{b}$ & $749.18^{\mathrm{a}}$ & $578.59^{b}$ & $598.78^{b}$ & 0.0000 \\
\hline ADF (g) intake & $423.26^{b}$ & $521.82^{a}$ & $421.60^{\mathrm{b}}$ & $423.82^{b}$ & 0.0002 \\
\hline Hemicell(g) intake & $201.46^{\mathrm{ab}}$ & $227.36^{a}$ & $156.99^{c}$ & $174.96^{\mathrm{bc}}$ & 0.0000 \\
\hline $\mathrm{CP}(\mathrm{g})$ intake & $173.73^{b}$ & $203.91^{\mathrm{a}}$ & $180.73^{\mathrm{ab}}$ & $198.60^{\mathrm{ab}}$ & 0.0228 \\
\hline Urea intake (g) & $0.00^{\mathrm{b}}$ & $0.00^{\mathrm{b}}$ & $4.48^{\mathrm{a}}$ & $4.24^{\mathrm{a}}$ & 0.0000 \\
\hline Bicarbonate intake (g) & $0.00^{\mathrm{b}}$ & $2.84^{\mathrm{a}}$ & $0.00^{\mathrm{b}}$ & $2.48^{\mathrm{a}}$ & 0.0000 \\
\hline MW intake gDM $/ \mathrm{kg}^{0,75}$ & $118.18^{\mathrm{ab}}$ & $139.08^{a}$ & $124.72^{\mathrm{ab}}$ & $105.63^{b}$ & 0.0013 \\
\hline MW intake $\mathrm{gCP} / \mathrm{kg}^{0,75}$ & $18.00^{\mathrm{b}}$ & $20.69^{a}$ & $18.33^{\mathrm{b}}$ & $20.24^{\mathrm{a}}$ & 0.0000 \\
\hline ADDM $(\%)$ & $36.98^{\mathrm{a}}$ & $37.88^{\mathrm{a}}$ & $34.94^{\mathrm{a}}$ & $39.35^{\mathrm{a}}$ & 0.4828 \\
\hline ADOM (\%) & $67.96^{\mathrm{a}}$ & $57.35^{\mathrm{b}}$ & $66.39^{\mathrm{a}}$ & $72.00^{\mathrm{a}}$ & 0.0000 \\
\hline DNDF (\%) & $30.88^{\mathrm{ab}}$ & $37.11^{\mathrm{a}}$ & $26.00^{b}$ & $30.70^{\mathrm{ab}}$ & 0.0161 \\
\hline DADF (\%) & $25.62^{\mathrm{ab}}$ & $31.26^{\mathrm{a}}$ & $22.46^{b}$ & $31.74^{\mathrm{a}}$ & 0.0090 \\
\hline DHEMICELL (\%) & $53.65^{\mathrm{ab}}$ & $56.30^{\mathrm{a}}$ & $43.35^{b}$ & $26.33^{c}$ & 0.0000 \\
\hline GEDIG (\%) & $33.06^{\mathrm{a}}$ & $31.33^{\mathrm{a}}$ & $30.38^{\mathrm{a}}$ & $35.31^{\mathrm{a}}$ & 0.3851 \\
\hline $\operatorname{ADCP}(\%)$ & $51.91^{\mathrm{a}}$ & $42.88^{b}$ & $42.17^{b}$ & $57.15^{a}$ & 0.0000 \\
\hline
\end{tabular}

MW: metabolic weight. ADDM: Apparent Digestibility of Dry Matter, ADOM: Apparent Digestibility of Organic Matter, DNDF: Digestibility of Neutral Detergent Fiber, DADF: Digestibility of Acid Detergent Fiber, DHEMICELL: Digestibility of Hemicellulose, GEDIG: Digestible Energy, ADCP: Apparent digestibility of crude protein. Different letters in the same row indicate significant differences $(a, b$ and $c)$.

When analyzing the independent effects of the factors of the arrangement, Table 6, it can be seen that for the $1 \%$ bicarbonate factor, it showed the highest values for intake of cell wall components (NDF, ADF, hemicellulose) and protein and apparent digestibility of NDF, ADF and CP; being similar 0 and $1 \%$ for intake and apparent digestibility of DM, OM and digestible energy. Urea factor at the $0 \%$ level presented the highest values for intake of cell wall components (NDF, ADF, hemicellulose) and for the apparent digestibility of NDF and hemicellulose; being the level 1\% of the factor Urea superior in intake of $\mathrm{OM}$ and apparent digestibility of the $\mathrm{OM}$ and CP. There was an interaction effect between the Bicarbonate and Urea factors for DM, NDF, ADF and apparent digestibility of OM, hemicellulose and CP.

Table 7 shows the results based on eight observations per treatment and expressed every 14 days that was the time of change between each treatment of the arrangement, where clearly the best weight gain was that of $\mathrm{T}_{4}$, followed by $\mathrm{T}_{1}$ and the worst $\mathrm{T}_{2}$ and $\mathrm{T}_{3}$, the daily intake of DM was higher for $\mathrm{T}_{2}$ and $\mathrm{T}_{3}$ (Table 5), although no differences were detected when globalizing it every 14 days, to make it related to the weight gain in the same period and obtain the conversion. But it gives a very approximate idea to confirm that the best conversion can be that of $\mathrm{T}_{4}$. 
Table 6. Analysis of Variables for intake and digestibility by factors evaluated and inclusion levels.

\begin{tabular}{|c|c|c|c|c|c|c|c|}
\hline \multirow{2}{*}{ Variables } & \multicolumn{2}{|c|}{ Sodium Bicarbonate } & \multirow{2}{*}{$\mathbf{P}$} & \multicolumn{2}{|c|}{ Urea } & \multirow{2}{*}{$\mathbf{P}$} & \multirow{2}{*}{ Interacction } \\
\hline & $0 \%$ & $1 \%$ & & $0 \%$ & $1 \%$ & & \\
\hline DM (g) intake & $1085.5^{\mathrm{a}}$ & $1152.5^{\mathrm{a}}$ & 0.1591 & $1149.4^{\mathrm{a}}$ & $1088.6^{a}$ & 0.2010 & 0.0082 \\
\hline OM (g) intake & 783.65 a & $769.82^{a}$ & 0.6722 & $727.68^{b}$ & $825.79 a$ & 0.0030 & 0.1393 \\
\hline NDF $(g)$ intake & $601.66^{b}$ & $673.98^{a}$ & 0.0074 & $686.95^{a}$ & $588.69^{b}$ & 0.0003 & 0.0526 \\
\hline$A D F(g)$ intake & $422.43^{b}$ & $472.82^{a}$ & 0.0080 & $472.54^{a}$ & $422.71^{b}$ & 0.0087 & 0.0112 \\
\hline Hemicell(g) intake & $179.23^{b}$ & $201.16^{a}$ & 0.0062 & $214.41^{a}$ & $165.98^{b}$ & 0.0000 & 0.6174 \\
\hline CP $(\mathrm{g})$ intake & $177.23^{b}$ & $201.26^{a}$ & 0.0028 & $188.82^{a}$ & $189.67 \underline{a}$ & 0.9154 & 0.4402 \\
\hline Urea intake (g) & $2.24^{a}$ & $2.12^{\mathrm{a}}$ & 0.3285 & $0.00^{\mathrm{b}}$ & $4.36^{a}$ & 0.000 & 0.3285 \\
\hline Bicarbonate intake (g) & $0.00^{b}$ & $2.66^{\mathrm{a}}$ & 0.000 & $1.42^{\mathrm{a}}$ & $1.24^{\mathrm{a}}$ & 0.4406 & 0.4406 \\
\hline MW intake g DM/kg ${ }^{0,75}$ & $111.37^{b}$ & $117.31^{\mathrm{a}}$ & 0.0203 & $117.87^{\mathrm{a}}$ & $110.81^{b}$ & 0.0059 & 0.0000 \\
\hline MW intake $\mathrm{g} \mathrm{CP} / \mathrm{kg}^{0,75}$ & $18.16^{b}$ & $20.47^{a}$ & 0.0000 & $19.34^{\mathrm{a}}$ & $19.28^{a}$ & 0.8905 & 0.3678 \\
\hline ADDM (\%) & $35.96^{\mathrm{a}}$ & $38.58^{\mathrm{a}}$ & 0.2019 & $37.40^{\mathrm{a}}$ & $37.15^{\mathrm{a}}$ & 0.9001 & 0.3853 \\
\hline ADOM (\%) & $67.18^{a}$ & $64.67 \underline{a}$ & 0.1916 & $62.66^{b}$ & $69.20^{\mathrm{a}}$ & 0.0007 & 0.0000 \\
\hline DNDF (\%) & $28.44^{b}$ & 33.91 a & 0.0215 & $34.00^{\mathrm{a}}$ & $28.35^{b}$ & 0.0176 & 0.7442 \\
\hline DADF (\%) & $24.04^{b}$ & $31.50 \mathrm{a}$ & 0.0011 & $28.44^{a}$ & $27.10^{a}$ & 0.5493 & 0.4188 \\
\hline DHEMICELL (\%) & 48.50 a & $41.32^{b}$ & 0.0188 & 54.97ạ & $34.84^{b}$ & 0.0000 & 0.0014 \\
\hline GEDIG (\%) & $31.72^{\mathrm{a}}$ & $33.32^{a}$ & 0.4582 & $32.19 \underline{a}$ & $32.84^{a}$ & 0.7642 & 0.1250 \\
\hline ADCP (\%) & $47.04 \underline{a}$ & 50.01 a & 0.1189 & $47.39 a$ & 49.66ạ & 0.2342 & 0.0000 \\
\hline
\end{tabular}

MW: metabolic weight. ADDM: Apparent Digestibility of Dry Matter, ADOM: Apparent Digestibility of Organic Matter, DNDF: Digestibility of Neutral Detergent Fiber, DADF: Digestibility of Acid Detergent Fiber, DHEMICELL: Digestibility of Hemicellulose, GEDIG: Digestible Energy, ADCP: Apparent digestibility of crude protein. Different letters in the same row indicate significant differences (a, b and c).

Table 7. Analysis of Variables for weight gain, intake and conversion by Evaluated Factors and inclusion levels.

\begin{tabular}{cccccc}
\hline \multirow{2}{*}{ Variables } & \multicolumn{4}{c}{ Sodium Bicarbonate Urea } & \multirow{2}{*}{ P Interacción } \\
\cline { 2 - 5 } & $\mathbf{0 \%}$ & $\mathbf{1 \%}$ & $\mathbf{0 \%}$ & $\mathbf{1 \%}$ & \\
\cline { 2 - 5 } & $\mathbf{T}_{1}$ & $\mathbf{T}_{\mathbf{3}}$ & $\mathbf{T}_{2}$ & $\mathbf{T}_{4}$ & \\
\hline Daily weight gain $(\mathrm{kg})$ & $0.084^{\mathrm{ab}}$ & $0.053^{\mathrm{b}}$ & $0.088^{\mathrm{ab}}$ & $0.131^{\mathrm{a}}$ & 0.0837 \\
Weight gain 14 d (g) & $1.356^{\mathrm{ab}}$ & $0.875^{\mathrm{b}}$ & $1.225^{\mathrm{b}}$ & $1.969^{\mathrm{a}}$ & 0.0193 \\
DM Intake 14 d (kg) & 14.37 & 14.73 & 16.31 & 14.25 & 0.4900 \\
Conversion kg DM / kg live weight gain & 16.96 & 19.14 & 14.47 & 10.07 & 0.3502 \\
\hline
\end{tabular}

Different letters in the same row show different means by the LSD test $(p<0.05)$

\section{DISCUSSION}

López-Yáñez et al (20) Pelibuey (West African) male lambs with an average live weight (LW) of $18.3 \pm 1.21 \mathrm{~kg}$ confined by consuming rations with dry distiller s grain $30.0 \%$, corn ground grain $51.5 \%$, sugar cane molasses $15.0 \%$, Premix mineral-protein 3.5\% Dry matter 95.5\%, Raw protein 16.7\%, Nitrogen free extract 36.2\%, Ethereal extract 4.0\%, NDF 35, 3\%, ADF 14.4\%, Ashes 5.2\%, achieving a DM intake of $1.120 \mathrm{~g} /$ day with an estimated DM degradability of 46.9\%, the intake being similar to this experiment and the degradability higher than the apparent digestibility. Bonilla-Cárdenas et al (21) in Pelibuey sheep of $40 \mathrm{~kg}$ of average body weight, confined by consuming rations with $60.7 \%$ of corn stubble, $24.6 \%$ of dried distillers grains with solubles, $10.6 \%$ of canola, $2.1 \%$ molasses and $1.1 \%$ calcium carbonate, whose composition was $87.2 \%$ DM, 89.6\% OM, 10.4\% ash, 15\% CP, 53.9\% NDF, 30.2\% \% ADF and 21.8\% of hemicellulose achieved intakes of $860.2 \mathrm{~g}$ of DM, $770.6 \mathrm{~g}$ of OM, $129.3 \mathrm{~g}$ of CP, $518 \mathrm{gr}$ of NDF, $330 \mathrm{~g}$ of ADF and $188 \mathrm{~g}$ of hemicellulose per animal per day, with apparent digestibility of $67.6 \%$ DM, 47.5\% OM, 63.5\% CP, 34.4\% NDF, 18.4\% ADF and 62.4\% for hemicellulose; the results of this experiment were superior in intake for most of the treatments and components analyzed, as well as for the digestibility of the OM, NDF and ADF, and lower for the digestibility of the DM, CP and hemicellulose.

Castro-Pérez et al (12) using Katahdin male lambs weighing $25.9 \pm 2.9 \mathrm{~kg}$, receiving rations with dry rolled corn 44.5 to $54.5 \%$, dry distillers grains with solubles 20 to $30 \%$, soy cake $5 \%$, Sudan grass hay $10 \%$, tallow 1.5 and molasses $6.1 \%$ whose final composition was CP 13.98 to $15.51 \%$, EE 5.38 to $5.95 \%$ NDF 22.55 to $26 \%, 12 \%$ and GE 18.32 to 18.41 MJ / $\mathrm{kg}$ and with a DM intake of 684 to $689 \mathrm{~g} / \mathrm{d}$, of OM of 639 to $646 \mathrm{~g} / \mathrm{d}$ and NDF of 154 to $180 \mathrm{~g} / \mathrm{d}$ and digestibility of the DM from 76.7 to $74.9 \%$, from OM 79.3 to $77.3 \%$ and from the NDF from 57.1 to $59.2 \%$; reaching lower values of fiber intake and much higher digestibility of the same, being relatively similar in the apparent digestibility of OM, both experiences. Despite having similar levels of distillery grains, the rations of Castro-Pérez et al (12) were much more concentrated in easily degradable energy (non-structural carbohydrates) and less fibrous, which would explain their greater digestion.

Curzaynz et al (22) formulated a base diet with 15\% forage (stubble of ground corn) and 85\% concentrate (corn, 47.3\%, soybean paste, $12.8 \%$, wheat bran, $7 \%$, gluten of corn, $7 \%$, molasses, $6 \%$, fat surpassing $2.4 \%$, calcium carbonate, $1.0 \%$, minerals $1.0 \%$ and salt $0.5 \%$ ), containing $18.5 \%$ CP, in the which included dried distiller grains with soluble in 20 and 
$40 \%$, partially replacing corn, soybean paste and corn gluten to maintain iso-nitrogenated experimental diets, which were offered to whole Creole lambs of $24 \pm 2.41 \mathrm{~kg} \mathrm{LW}$ reaching intakes of 1261 to $1281 \mathrm{~g} / \mathrm{animal} / \mathrm{d}$ and apparent digestibility of the DM of $75.3170 .1 \%$, NDF of 49.5 to $45.1 \%$ and ADF of 44.8 to $40.4 \%$ for the rations of 20 and $40 \%$ of distillery grains, the results of them exceed intakes and digestibility to all treatments and are similar in intake to $\mathrm{T}_{\text {, }}$, something similar to the previous comparison where a ration was evaluated Highly concentrated and relatively low in fiber.

Miccoli et al (23) using sheep with ruminal fistula (70.0 $\pm 7.13 \mathrm{~kg}$ of LW), using as treatments: dried distillers grains with solubles (DM 75.4\%, PB 27.3\%, NDF 46.8\%; ADF 12.3\%; EE 12.3\%); Soybean Expeller (DM 97.0\%, PB 40.4\%, FDN 20.2\%, ADF 7.0\%, EE 12.31\%); sunflower pellet (PG) (DM 96.3\%, PB 36.6\%, NDF 31.0\%, ADF 18.0\%, EE 6.7\%) and pasture hay (HP) (DM 96.4\% PB 7.0\%, NDF 70.4\%, ADF 36.8\%, EE 1.5\%) as basal diet; digestion was 47.4\% of the DM, $51.4 \%$ of the OM, $47.1 \%$ of the NDF and $32.3 \%$ of the ADF, when the supplementation represented $52 \mathrm{~g}$ of DM for each kg of $\mathrm{PV}^{0.75}$ and that of hay of $51 \mathrm{~g}$ of DM for each $\mathrm{kg}$ of PV ${ }^{0.75}$; being a lower performance both in metabolic weight intake and in digestibility with respect to $\mathrm{T}_{2}$ and $\mathrm{T}_{4}$ of this experiment, probably due to the positive effect of molasses as a source of non-structural carbohydrates of easy degradation and digestion.

Arcos-García et al (24) evaluating Suffolk Sheep, weighing 30kg, that received a consistent base ration, on a dry basis, of sugar cane core $(50 \%)$, sorghum grain $(21 \%)$, wheat bran $(15 \%)$, molasses $(12 \%)$ and urea (2\%), having the following composition: $90.23 \%$ DM; $92.37 \%$ of OM; $11.47 \%$ CP; $62.57 \%$ of NDF; and $28.45 \%$ of ADF, to which Saccharomyces cerevisiae was added or not as a complement, reaching a dry matter intake of $1401 \mathrm{~g} / \mathrm{d}$, a digestibility of DM 79.3\%; 0M 89.1\%; NDF 32.1\%; and ADF of 18.6\%, achieving better performance in the digestion of the DM and OM, similar in the $\mathrm{NDF}$ and lower in the ADF than in this trial, with similar rations in the structural carbohydrate content of the cell wall.

Aguirre et al (25) evaluated the animal response using male lambs, Pelibuey breed, weaned with average live weight of $20.24 \pm 3.17 \mathrm{~kg}$ confined with selected diets based on the whole milled sugar cane (ammoniated and enriched with zeolite) at $50 \%$ of the ration and the other $50 \%$ was a mixture of whole corn flour and soybean cake, for a $13.25 \%$ of $\mathrm{CP}$ and $59.1 \%$ of NDF and $37.7 \%$ of ADF, achieved an individual intake of $1.405 \mathrm{~g}$ of DM/animal/d, with weight gain of 106.5 $\mathrm{g} \mathrm{LW} /$ animal/d, being lower in weight gain and higher in DM intake at $\mathrm{T}_{4}$ of this experiment, which is of interest since there is no corn and soy in the ration. Although Aguirre et al (25), have an experience using sugar cane harvest residues and sugar cane silage without ammonification (to $50 \%$ of the ration) also with soybean cake and corn integral flour with $10.9 \%$ of CP and 59.95 of NDF, where achieved intake of 1,350 g DM / animal / d and $130.7 \mathrm{~g} \mathrm{LW} \mathrm{/} \mathrm{animal} \mathrm{/} \mathrm{d} \mathrm{being} \mathrm{similar}$ in weight gain to $\mathrm{T}_{4}$, but higher in the intake, which means less conversion, with the same incorporation of soybean cake and corn.

Pedraza et al (26) evaluating Pelibuey sheep of $14.2 \mathrm{~kg}$ of LW, fed with "B" cane molasses and Digitaria decumbens hay sprayed with a solution of a urea-molasses mixture offered ad libitum, receiving as a supplement three levels of inclusion of saccharina (40 to 60\%), sugar cane (10 to 20\%) and brown sugar sweeping (17\%), reached weight gains of 81 to $127 \mathrm{~g}$ LW / animal / day, the best treatment being the one 40\% saccharin, $18 \%$ sunflower meal, $17 \%$ brown sugar sweep, with a conversion of $10.9 \mathrm{~kg} \mathrm{DM} / \mathrm{kg}$ of LW gained, being similar in weight gain to $\mathrm{T}_{4}$, with a slightly higher conversion, despite to have used molasses, $117 \mathrm{~g} \mathrm{DM}$ / animal / day of molasses, sweeping sugar and sunflower cake, whose nutritional value is high.

Rivas-Jacobo et al (27) evaluated the supplementation with humid brewery bagasse (BHC) in substitution of a grain of corn and sorghum in the productivity of Rambouillet sheep of $25.5 \mathrm{~kg}$ of LW grazing on crop residues (Zea mays L. and Avena sativa L.) receiving $500 \mathrm{~g}$ of DM from BHC as a supplement reached weight gains of $138.8 \mathrm{~g} / \mathrm{animal} / \mathrm{d}$, values similar to those found in this experiment.

Obeidat (28) evaluated Awassi lambs of 24.9 $\pm 1.93 \mathrm{~kg} \mathrm{LW}$, to which they were offered a completely mixed ration of barley grain, soybean cake and 15\% dried distillers grains with solubles, consuming 1,059 g DM / animal / d and achieving live weight gain of $212 \mathrm{~g} /$ animal / $\mathrm{d}$ and a conversion of $5.03 \mathrm{~kg}$ of DM / $\mathrm{kg}$ of LW gained, much higher than $\mathrm{T}_{4}$.

Obeidat et al (29) was to evaluate the effect of feeding low (LO)- or high (HI)-fiber diets supplemented with Saccharomyces cerevisiae (0.25 gr/day/lamb), Awassi female lambs (6 months old) were used, diet HI was $13.8 \% \mathrm{CP}, 52 \% \mathrm{NDF}, 21.9 \%$ $\mathrm{ADF}$; the DM and CP intake were $1143 \mathrm{~g} / \mathrm{d}$ and $158 \mathrm{~g} / \mathrm{d}$; digestibility were: DM 66\%, CP 70.2\%, NDF 59.8\% and ADF $60.9 \%$. This experience had a similar performance in the DM intake and higher in all the digestible fractions evaluated than the one achieved here, this was surely marked by a soybean and barley grain content of $43 \%$ and only $43 \%$ of wheat straw.

The possibility of supplementing ammoniated forage with molasses and distillery grains to an ammoniated forage, significantly improves the weight gains in lambs, because Rodríguez-Prado and Ventura (2) in crossbred West African lambs receiving ammoniated hay from Brachiaria humidicola could only achieve weight gains of $27 \mathrm{~g} \mathrm{LW} / \mathrm{animal} / \mathrm{d}$.

The higher intake of sodium bicarbonate and urea in the ration of T4 (Table 5) allowed a higher intake of raw protein and organic matter; likewise, a greater apparent digestibility of dry matter, organic matter, crude protein, NDF and ADF in said treatment was achieved; This resulted in greater weight gain in such treatment. These achievements are based on the possibility of having a higher $\mathrm{pH}$, close to neutrality (6.2 to 6.7), and a longer retention time of ammonia in the ruminal liquor without being absorbed by the ruminal wall, allowing a greater Synthesis of microbial protein and lower loss of energy in urea synthesis for urinary removal, evidenced by the lower intake of dry matter of T4 and the higher intake of crude protein, of which almost a third or more was non-protein nitrogen (urea and ammoniated forage), as supported by the findings of Lu et al (30); Sartre et al (31); Hsu et al (32); Xu et al (33) and Phillip (34). 
In conclusion, low-value local resources for the nutrition of human and non-ruminants, such as sugarcane harvest byproducts of and the liquor industry by-products in the feeding of weaned lambs, using of sodium bicarbonate and urea as improvers of ruminal function. Production tests must be carried out on a larger scale to determine the economic value of the evaluated practice.

\section{Conflict of interest}

We certify that there is no conflict of interest with any financial organization regarding the material discussed in the manuscript.

\section{Acknowledgments}

To the CDCHT of the Lisandro Alvarado University for partially financing the present investigation with the Project 534AG-2007 and Mr. Orlando Alvarado Polanco for his support and partial funding of the investigation.

\section{REFERENCES}

1. Freer M, Dove H. Sheep Nutrition. CAB International, CABI Publishing, Wallingford, UK; 2002. URL: https://trove.nla. gov.au/version/44883421.

2. Rodríguez-Prado M, Ventura M. Suplementación con melaza y harina de maíz en corderos alimentados con heno amonificado. Arch. Latinoam. Prod. Anim. 2009; 17(1-2):31-35. URL: http://www.bioline.org.br/pdf?la09005

3. Nouel-Borges G, Hevia Opazo P, Velásquez M, Espejo Días M, Rojas J, Sánchez R. Efecto de cama de pollos, subproductos de cereales y caña sobre la fisiología ruminal de ovinos. Archivos de Zootecnia. 2011; 60(229):19-30. URL: http:// www.uco.es/organiza/servicios/publica/az/php/img/web/09_1023 03EfectoBorges.pdf

4. Nouel-Borges G, Hevia-Opazo P, Sánchez-Blanco R, Rojas-Castellanos J, Velásquez M. Producción de corderos alimentados con raciones de bagazo de caña amonificado, subproductos de maíz y cama de pollos, confinados hasta el sacrificio. Revista Científica, FCV-LUZ. 2013; 23(6):520-530. URL: http://www.fcv.luz.edu.ve/index.php?option=com content\&task=view\&id=567\&Itemid $=186$

5. FAOSTAT. FAO. Sugar cane production, yield and area harvested in Venezuela year 2014 (On line). Fao; 2019. http:// www.fao.org/faostat/en/\#data/QC

6. Galina MA, Ruiz G, Ortiz MA. Ceba de bovinos con punta de caña y planta de maíz suplementados con bloque proteico de urea o concentrado. Pastos y Forrajes. 2002; 25(3):1-12. URL: https://payfo.ihatuey.cu/index. php?journal=pasto\&page=article\&op=view\&path $\% 5 B \% 5 \mathrm{D}=869$

7. HernándezA,MujicaA.Optimización del proceso deamonificación en secoyvalornutritivo delbagacillo decaña en ovinos. Universidad NacionalExperimentalPolitécnicaAntonioJosédeSucre.Barquisimeto:Venezuela;2003.URL: http://bibagr. ucla.edu.ve/cgi-win/be alex.exe?Acceso=T070500043174/0\&Nombrebd=bvetucla\&Destacar=antonio;hernandez

8. Kebede G, Mengistu A, Assefa G, Animut G. Nutritional and fermentative quality of sugarcane (Saccharum officinarum) top ensiled with or without urea and molasses. African Journal of Agricultural Research. 2018; 13(20):1010-1017. DOI: https://doi.org/10.5897/AJAR2017.12888

9. Andrade-Benítez OC. Demarcaciones climáticas del municipio Torres en el estado Lara, Venezuela. Agronomía Trop. 2012; 62(1-4):97-110. URL: http://www.sian.inia.gob.ve/revistas ci/Agronomia\%20Tropical/at621-4/pdf/at6214 andrade 0.pdf

10. MPPAT (Ministerio del poder popular para la Agricultura y Tierras). VII censo agrícola nacional (mayo 2007 / abril 2008) Procesado con Redatam+SP CEPAL/CELADE. 2008. URL: http://censo.mat.gob.ve/

11. Nouel-Borges G, Rincón-González J. Potencial forrajero de especies arbóreas en el bosque seco tropical \#12. En: Manual de Ganadería Doble Propósito. González-Stagnaro C, Soto-Belloso E. (ed). Ediciones Astro Data, S.A: Maracaibo, Venezuela; 2005. URL http://www.avpa.ula.ve/docuPDFs/libros online/manual-ganaderia/seccion3/articulo12-s3. pdf

12. Castro-Pérez BI, Garzón-Proaño JS, López-Soto MA, Barreras A, González VM, Plascencia A, et al. Effects of replacing dry-rolled corn with increasing levels of corn dried distillers grains with solubles on characteristics of digestion, microbial protein synthesis and digestible energy of diet in hair lambs fed high-concentrate diets. Asian Australasian Journal of Animal Science 2013; 26(8):1152-1159. DOI: https://doi.org/10.5713/ajas.2013.13054 
13. Todorov N, Simeonov M, Kirilov A. Feeding early-weaned lambs with pelleted dry distillers grain with solubles (DDGS) plus whole grain, and two methods of supplyng minerals and vitamins. Bulgarian Journal of Agricultural Science. 2013; 19(4):810-816. URL: https://www.agrojournal.org/19/04-30.pdf

14. Whitney TR, Braden KW. Substituting corn dried distillers grains for cottonseed meal in lamb finishing diets: carcass characteristics, meat fatty acid profiles, and sensory panel traits. Sheep \& Goat Research Journal 2010; 25:49-56. http://d1cqrq366w3ike.cloudfront.net/http/DOCUMENT/SheepUSA/Substituting-Corn-Dried-Distillers-GrainsCottonseed-Meal.pdf

15. Ortiz JN, Miranda H, Peroza D. Uniformidad y pérdidas por evaporación y arrastre en riego por aspersión en Tarabana, estado Lara. Revista Unellez de Ciencia y Tecnología 2015; 33:53-61. http://revistas.unellez.edu.ve/index.php/ruct/ article/download/246/234

16. AOAC. Official methods of analysis. 14th ed., Association of official agricultural chemist. Washington, DC.; 1984.

17. Van Soest PJ, Robertson JB, Lewis BA. Methods for dietary fibre, neutral detergent fibre, and nonstarch polysaccharides in relation to animal nutrition. Journal of Dairy Science 1991; 74:3583-359. https://doi.org/10.3168/jds.S00220302(91)78551-2

18. Preston T. Tropical Animal Feeding. Animal Production And Health Paper \# 126. FA0: Roma; 1995. http://www.fao. org/3/V9327E/V9327E00.htm

19. Analytical Software®. Statistix for Windows Version 8.0. 2105 Miller Landing Rd Tallahassee, FL 32312 USA: Analytical Software; 2007.

20. López-Yáñez BA, Pinos-Rodríguez JM, Devezé-Murillo P, Espin T, Pérez-Hernández P. Efecto de la substitución de maíz por cormo de malanga (Colocasia esculenta) en la degradación in vitro de dietas y en el desarrollo de corderos Pelibuey. Agrociencia. 2018; 52:97-105. https://www.colpos.mx/agrocien/Bimestral/2018/dic-especial/art-11.pdf

21. Bonilla-Cárdenas JA, Lemus-Flores C, Montaño-Gómez MF, González-Vizcarra VM, Ly-Carmenatti J. Fermentación ruminal, digestibilidad y producción de metano en ovinos alimentados con cuatro niveles de rastrojo de maíz. Tropical and Subtropical Agroecosystems 2012; 15:499-509. www.revista.ccba.uady.mx/ojs/index.php/TSA/article/ download/1446/760

22. Curzaynz, KR, Bárcena JR, Hernández D, Herrera JG, Crosby MM, Sánchez C, Meneses M. Efecto de los granos secos de destilería en dietas iso-nitrogenadas en el comportamiento productivo, variables ruminales, digestibilidad y características de la canal en corderos. Reunión Nacional de Innovación Acuícola y Pesquera. Instituto Nacional de Investigaciones Forestales, Agrícolas y Pecuarias (INIFAP): México D.F; 2014 http://reunionesnacionales.inifap.gob. mx/RNIP/ MEMORIAS/2014.pdf

23. Miccoli F, Villanueva Pedraza E, Jaurena G, Wawrzkiewicz M, Iorio JD, Cantet JM, Palladino RA. NA1 Consumo y digestión de heno de forraje de baja calidad en ovinos suplementados con granos de destilería de maíz. Revista Argentina de Producción Animal 2015; Supl.1:259. http://ppct.caicyt.gov.ar/index.php/rapa/article/view/7177/pdf

24. Arcos-García JL, Castrejón FA, Mendoza GD, Pérez-Gavilan EP. Effect of two commercial yeast cultures with Saccharomyces cerevisiae on ruminal fermentation and digestion in sheep fed sugar cane tops. Livestock Production Science. 2000; 63(2):153-157. DOI: https://doi.org/10.1016/S0301-6226(99)00116-5

25. Aguirre J, Magaña R, Martínez S, Gómez A, Ramírez JC, Barajas R, Plascencia A, Bárcena R, García DE. Caracterización nutricional y uso de la caña de azúcar y residuos transformados en dietas para ovinos. Zootecnia Tropical. 2010; 28(4):489-497. http://ve.scielo.org/pdf/zt/v28n4/art05.pdf

26. Pedraza RM, Mauriño C, Gómez JE, Valdés V, Chaviano A. Alimentación post-destete de ovinos pelibuey con miel "B”, heno y mezclas basadas en derivados de la caña de azúcar. Livestock Research for Rural Development 1995; 7(2): Article \#12. http://www.lrrd.org/lrrd7/2/10.htm

27. Rivas-Jacobo M, Herrera-Medina R, Santos-Díaz R, Herrera-Corredor A, Escalera-Valente F, Martínez-González S. Bagazo húmedo de cervecería como sustituto de cereales en la suplementación de ovinos. Abanico Veterinario. 2017; 7(3):21-29. http://www.scielo.org.mx/pdf/av/v7n3/2448-6132-av-7-03-00021.pdf

28. Obeidat BS. Influence of corn-dried distiller's grain with solubles on growth performance and blood metabolites of Awassi lambs offered a concentrate diet. Italian Journal of Animal Science 2018; 17(3):636-642. https://doi.org/10. $\underline{1080 / 1828051 X .2017 .1404946}$

29. Obeidat BS, Mahmoud KZ, Obeidat MD, Ata M, Kridli RT, Haddad SG, Titi HH, Jawasreh KI, Altamimi HJ, Subih HS, Hatamleh SM, Ishmais MAA, Affan RA The effects of Saccharomyces cerevisiae supplementation on intake, nutrient digestibility, and rumen fluid pH in Awassi female lambs. Veterinary World. 2018; 11(7):1015-1020. https://doi. org/10.14202/vetworld.2018.1015-1020 
30. Lu Z, Stumpff F, Deiner C, Rosendahl J, Braun H, Abdoun K, Aschenbach JR, Martens H. Modulation of sheep ruminal urea transport by ammonia and pH. Am J Physiol Regul Integr Comp Physiol. 2014; 307:R558-R570. https://doi. org/10.1152/ajpregu.00107.2014

31. Santra A, Chaturvedi OH, Tripathi MK, Kumar R, Karim SA. Effect of dietary sodium bicarbonate supplementation on fermentation characteristics and ciliate protozoal population in rumen of lambs. Small Ruminant Research. 2003; 47:203-212. https://doi.org/10.1016/S0921-4488(02)00241-9

32. Hsu JT, Fahey Jr. GC, Clark JH, Berger LL, Merchen NR. Effects of urea and sodium bicarbonate supplementation of a high-fiber diet on nutrient digestion and ruminal characteristics of defaunated sheep. J Anim. Sci. 1991; 69(3):13001311. https://doi.org/10.2527/1991.6931300x

33. Xu Y, Li Z, Moraes LE, Shen J, Yu Z, Zhu W. Effects of Incremental Urea Supplementation on Rumen Fermentation, Nutrient Digestion, Plasma Metabolites, and Growth Performance in Fattening Lambs. Animals. 2019; 9:652-663. https://doi.org/10.3390/ani9090652

34. Phillip Le. Effect of sodium bicarbonate on nitrogen utilization and feed intake by lambs. Can J Anim Sci. 1983; 63:613621. https://www.nrcresearchpress.com/doi/pdf/10.4141/cjas83-069 